\title{
Damage Caused by the Furniture Beetle (Anobium punctatum) on Cultural and Historic Hardwood types "Case Study"
}

Mahmoud ALI
Lecturer, Conservation of Archaeology Department, Faculty of Archaeology, Luxor- Egypt. (dr.mahmoud.sayed82@gmail.com) 

— Damage Caused by the Furniture Beetle (Anobium punctatum) on Cultural and Historic Hardwood types "Case Study"

\title{
Damage Caused by the Furniture Beetle (Anobium punctatum) on Cultural and Historic Hardwood types "Case Study"
}

\author{
Mahmoud ALI ${ }^{(1)}$
}

\section{Abstract:}

This research is about the damage caused by the furniture beetle (Anobium punctatum) on the cultural and historic hardwood through a case study on cultural and historic artifacts in Nice-France, through studying five historic artifacts that were used for different purposes, such as old household items (old wooden coffee grinderold wooden box), old construction tools (old Mason's moulded brick jointer) and old carpentry tools (old wooden mallet- old wooden plane). All these artifacts were made out by of hardwoods (Fagus sylvatica L, Quercus robur L, Populus nigra L, Platanus occidentalis L), but in spite of their diversity, they have taken the same appearance of damage by furniture beetle (Anobium punctatum). This study begins with an introduction on the damages caused by the insects; Anobiidae family and furniture beetle (Anobium punctatum), followed by the identification the types of wood, the damage caused by the furniture beetle (Anobium punctatum) on selected artifacts and finally the conclusions.

Key words: Hardwood, Insects, Anobium punctatum, Damage.

1- Lecturer, Conservation of Archaeology Department, Faculty of Archaeology, Luxor- Egypt. (dr.mahmoud.sayed82@gmail.com ) 
Damage Caused by the Furniture Beetle (Anobium punctatum) on Cultural and Historic Hardwood types "Case Study"-

\section{1- Introduction}

The aim of this research is to identify types of wood which are used in ancient times in France, and to point out the damage caused by the furniture beetle (Anobium punctatum) on ancient wood, where the relevance of the Anobium punctatum damage is reflected by their incidence to a lot of ancient, cultural and historic wooden objects especially in Nice- France.

The reason to choose this topic is the spread of the insect damage in a lot of old wooden objects in NiceSouthern France and to identify the species of the insects that damage these old wooden objects. The insect damage is one of many main factors causing damage and loss of cultural heritage.

Insects are one of the most important and the most dangerous factors causing damage to the archaeological and cultural artifacts, and one of the factors involved in the destruction of ancient wood, without distinction of wood species or hardness. (Tsoumis.1991). especially in good conditions allowing their development and activity, such as temperature, humidity, air and wood which is their food source and habitat. The seriousness of the infestation in ancient and archaeological wood is the consequence of the difficulty to detect the infestation from early stages. (Feliden.2003). for that the appearance of the infestation such as holes, powder and faeces, insect parts, etc... Indicate the propagation of the infestation and damage caused by the insects. (Cronyn.1990)

\section{1-1- Anobiidae family:}

Anobiidae family is a type of the order Coleoptera, representing a family of small dimensions of about 1800 genera and divided into 8 subfamilies: Hedobiinae, Dryophilinae, Ernobiinae, Anobiinae, Ptilininae, 
Xyletininae, Tricoryninae şi Dorcatominae. (Mosneagu. 2012) The anobiids larvae which cause the damage of archaeological wood are very small in the first-stage area and take the straight shape and with growing older they take the curled shape, (Busvine.1980) their colour is white to yellowish (Unger, et al. 2001) and various lengths (4-11 mm). (Mosneagu. 2012). The larvae have strong mandibles (Busvine.1980) that are used to dig oval or round shaped holes in the damaged wood in addition to the tunnels. (Zabel, Morrell.1992),(Morrell.2008). Part of the wood is swallowed, digested and extruded as faeces in the form of small oval pellets, known as 'frass'. (Busvine.1980). They feed exclusively on wood throughout their life, (Teles.2001) which leads to increased damage inside the wooden piece, whereas only small holes appear on the surface. (Kretschmann.2010) these damages increase by time, where the existing holes grow to a 1-2 mm diameter (Unger.2001) during their life cycle from 1 to 2 years, (Kisternaya and Kozlov.2009) and they attack ancient hardwoods and softwoods with a moisture content $>12 \%$. (Jones et al, 2007). The adult insects of anobiids are small with a length $1.3-9 \mathrm{~mm}$, with brown colour and subcylindrical or oval body, which are covered with whitish or golden hairs that can sometimes form spots. (Mosneagu. 2012) Generally the damage caused by Anobiidae insects is most common in furniture and ancient wooden artifacts. These insects need a moderate temperature and high humidity for their growth and activity. (Tian. 2002) They also need a moisture content up to $15 \%$. (Clausen.1996)

\section{1-1-1- Furniture beetle (Anobium punctatum):}

Scientific name: Anobium punctatum (De Geer).

Taxonomy: Coleoptera, Anobiidae. 
Synonym: Anobium striatum (OI).

Anobium punctatum known as the common furniture beetle (Eaton and Hale. 1993) is a small beetle and the adults are from 2.5 to $5.0 \mathrm{~mm}$ in length with elongated and cylindrical shapes, reddish brown to dark brown or black in colours, with longitudinal rows of small pits on the elytra (wing covers) (Kaygin., et al., 2008). The upper surfaces of the body are clothed with fine short yellow hair (Munro, Hon. 1924) (Eaton and Hale. 1993). The exit holes for these insects are 1.6-3 $\mathrm{mm}$ in diameter. The larvae about $6 \mathrm{~mm}$ long, the colour of the larva is yellowish white with dark brown mandibles, the body is covered with scattered pale yellow hairs. (Robinson. 2005). Their eggs are visible, white, glossy, lemon- shaped and with length about $0.3 \mathrm{~mm}$ (Munro, Hon. 1924) (Unger.2001). Distribution: Europe, North America, South Africa, Australia and New Zealand. Damage characteristics are a circular exit hole with diameter about $1-2 \mathrm{~mm}$, and they attack all types of wood (Softwood- Hardwood) (Unger.2001).

\section{2- MATERIALS AND METHODS}

\section{2- 1- Artifacts studied:}

In this paper five old artifacts that were used in different usages were studied, such as old household items (wooden coffee grinder-wooden box), old construction tools (mason's moulded brick jointer) and old carpentry tools (wooden mallet- wooden plane), which had the same appearance of damage caused by the insects.

\section{2- 1- 1- Old wooden coffee grinder:}

Coffee grinders are among the most common and ancient kitchen utensils used in France, because of the 

on Cultural and Historic Hardwood types "Case Study"

high consumption of coffee in France. Grinders appeared in the late $17^{\text {th }}$ century, until the beginning of the industrial age. Even though they are various in shapes but they have the same technology. (Bianco.1999). This ancient wooden coffee grinder with dimension 12.2x12.2x19.9 cm manufacturer "Le Parfait Broyeur E.G Usines à Migennes (Yonne) marque déposée".
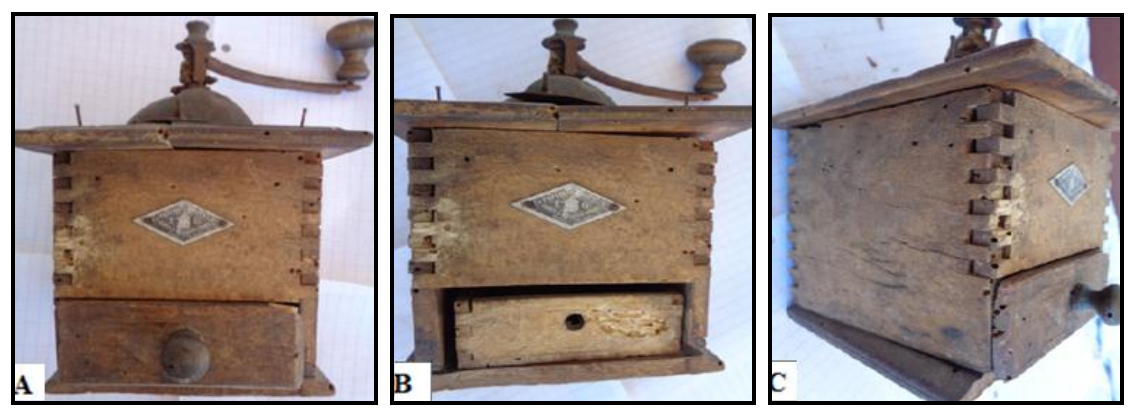

Fig.1. Old wooden coffee grinder

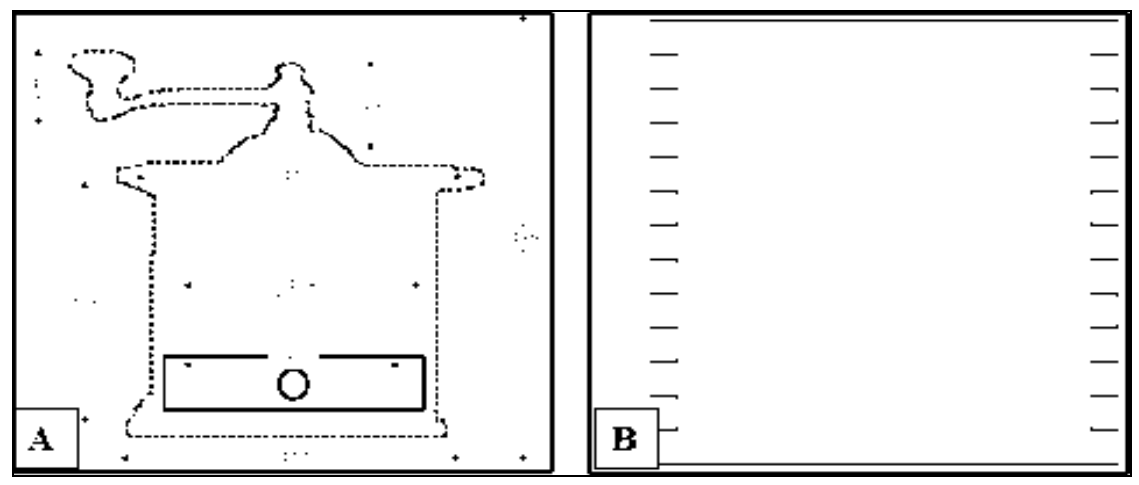

Fig.2. A. The dimension of the old wooden coffee grinder, B. the method of assembling the different wooden pieces.

\section{2-1-1-1- Wood used:}

The wood used for this ancient wooden coffee grinder was identified through examining the crosssection with a USB Digital Microscope and comparing with the standard. After examining all the pieces of wood used it turned out that they used several wood types, which are as follows: 
Damage Caused by the Furniture Beetle (Anobium punctatum) on Cultural and Historic Hardwood types "Case Study"

\section{2- 1- 1- 1- 1- Beech wood}

Fagus sylvatica L.

Family: Fagaceae

Beech wood is a wood with diffused pores (Jourez.2010), semi-hard, heavy and elastic. It has a creamy white colour, with pink tones. Its thread is straight and has a fine and homogeneous texture. It can resist heat, but is vulnerable to humidity and insect attacks (Richebé.2006). It is used in indoor carpentry, wooden floors, turned and fitted parts for rolling material and traverses (Benoit.2002). Beech wood was used for making a lot of parts in this coffee grinder such as the sides, the base and the upper part.

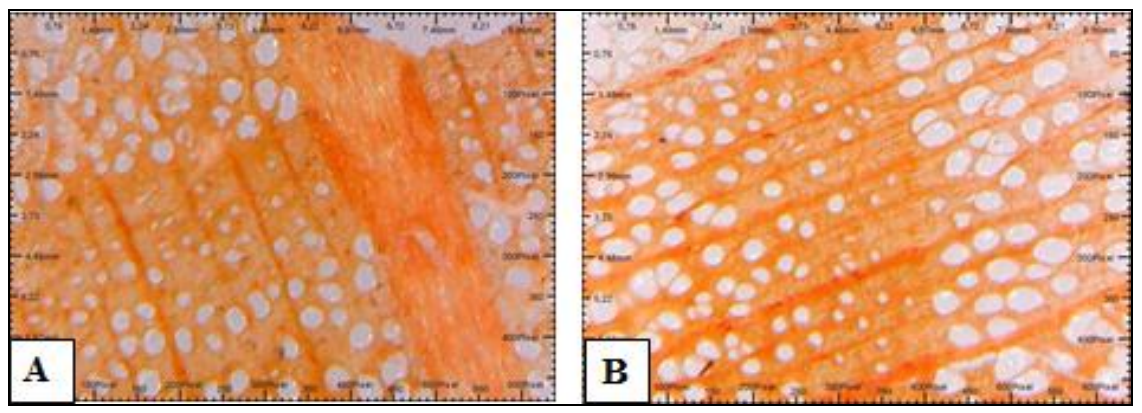

Fig.3. Cross-section of Fagus sylvatica L.

\section{2- 1- 1- 1- 2- Oak wood}

Quercus robur L.

Family: Fagaceae.

Oak wood is a wood with porous zones (ringporous wood) (Jourez.2010). It is one of the hardwood species which is very hard and dense, with light brown to yellowish brown colour. It has high mechanical properties and resistance to humidity. (Richebé.2006). Oak wood is used in indoor constructions, naval constructions, in carpentry for large furniture and wood 
- Damage Caused by the Furniture Beetle (Anobium punctatum) on Cultural and Historic Hardwood types "Case Study"

veneer (Bierling.2007). Oak wood was used to make the right side of the drawer.

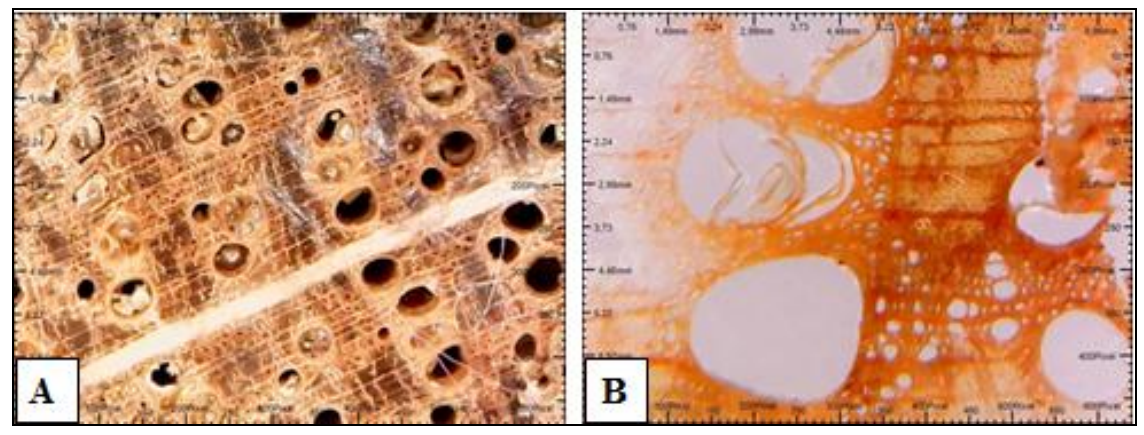

Fig.4. cross-section of Quercus robur $L$

\section{2- 1- 1- 1- 3- Poplar wood}

Populus nigra L.

Family: Salicaceae.

Poplar wood is a wood with diffused- pores. (Jourez.2010) It has a good weight-mechanical strength, but does not last long, it was used for light timber frames, indoor painted carpentry and crating. (Bierling.2007) This wood was used for making parts of the drawer such as the front part, the back part and the base.

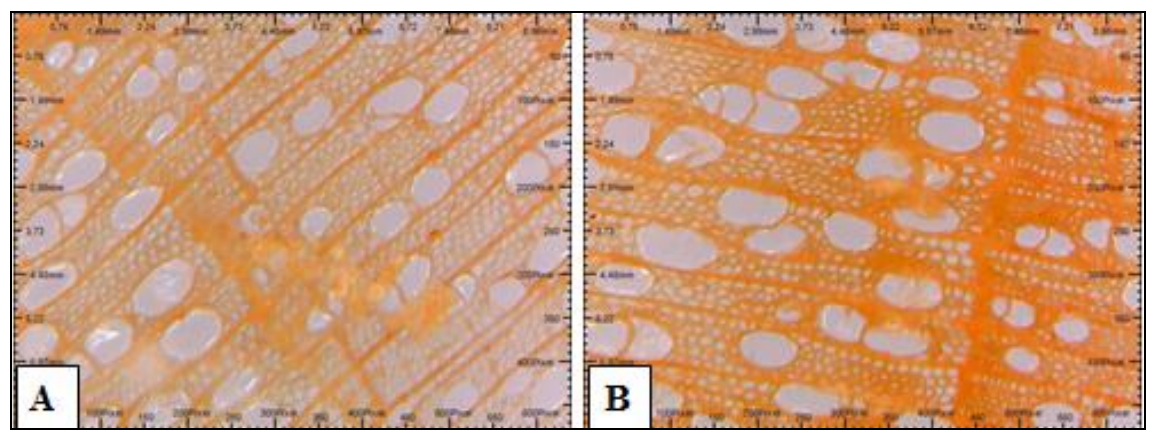

Fig.5. cross-section of Populus nigra L.

\section{2- 1- 1- 1- 4- Plane wood, Sycamore}

Platanus occidentalis $L$. 
Damage Caused by the Furniture Beetle (Anobium punctatum) on Cultural and Historic Hardwood types "Case Study"

Family: Platanaceae.

Plane wood is a wood with diffused- pores (Jourez.2010). This wood has uses and characteristics like beech wood. (Bierling.2007) Plane trees are used as ornamental trees in urban areas and for road alignment. It is also used for toys, wooden floors and coffins (Vilà.2013). This wood was used for the front part and the front left side of the grinder and the left side of the drawer.

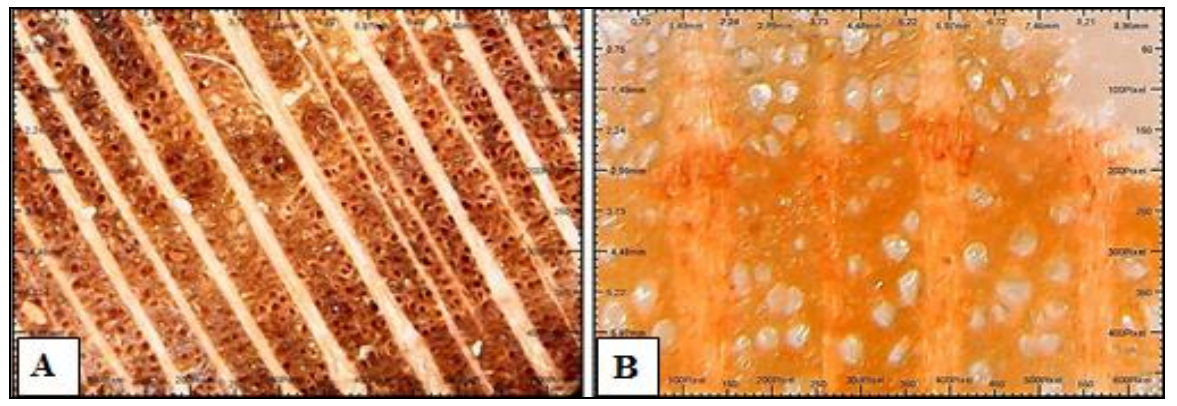

Fig.6. cross-section of Platanus occidentalis.L

\section{2- 1- 2- Old Mason's moulded brick jointer (fer à joint):}

It is one of the oldest construction tools, which was used by construction workers to remove excess cement mortar from the floor tiles, and the brick wall.
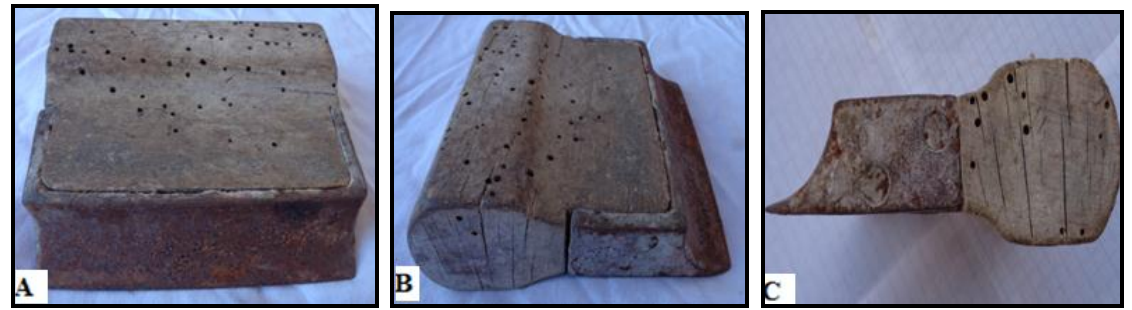

Fig.7. Old wooden Mason's moulded brick jointer 
- Damage Caused by the Furniture Beetle (Anobium punctatum) on Cultural and Historic Hardwood types "Case Study"

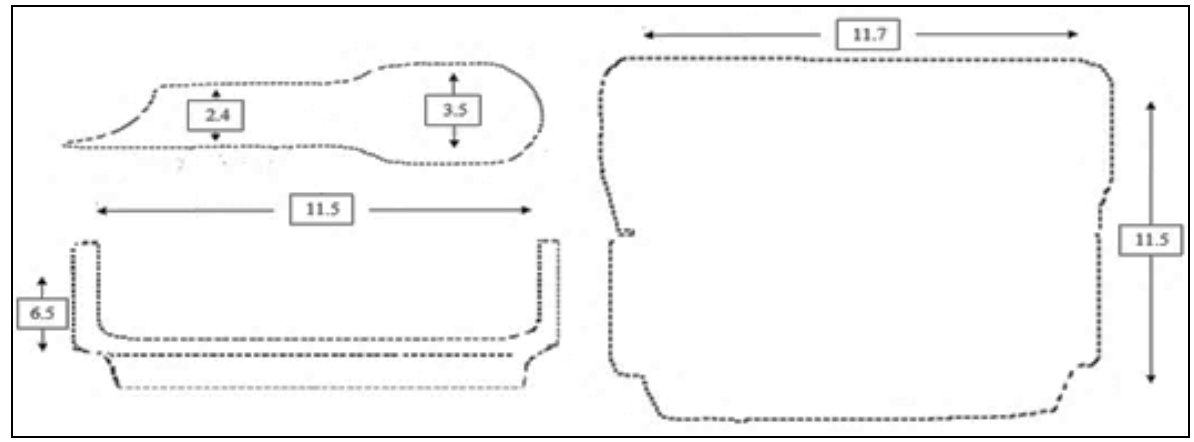

Fig.8. A. The dimension of old wooden Mason's moulded brick jointer

\section{2-1- 2-1- Wood used:}

\section{2- 1- 2- 1- 1- Beech wood}

Fagus sylvatica $L$.

Family: Fagaceae.
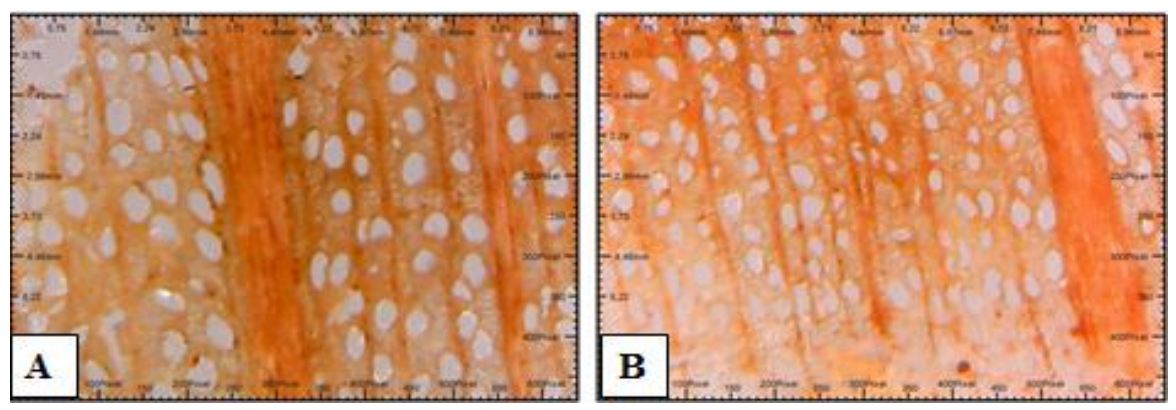

Fig.9. cross-section of Fagus sylvatica L.

\section{2- 1- 3- Old wooden Box:}

One of the household tools that were used to keep the salt dry or for keeping matches, this old wooden box with dimension $29.5 \times 18 \times 10 \mathrm{~cm}$. 
Damage Caused by the Furniture Beetle (Anobium punctatum) on Cultural and Historic Hardwood types "Case Study"

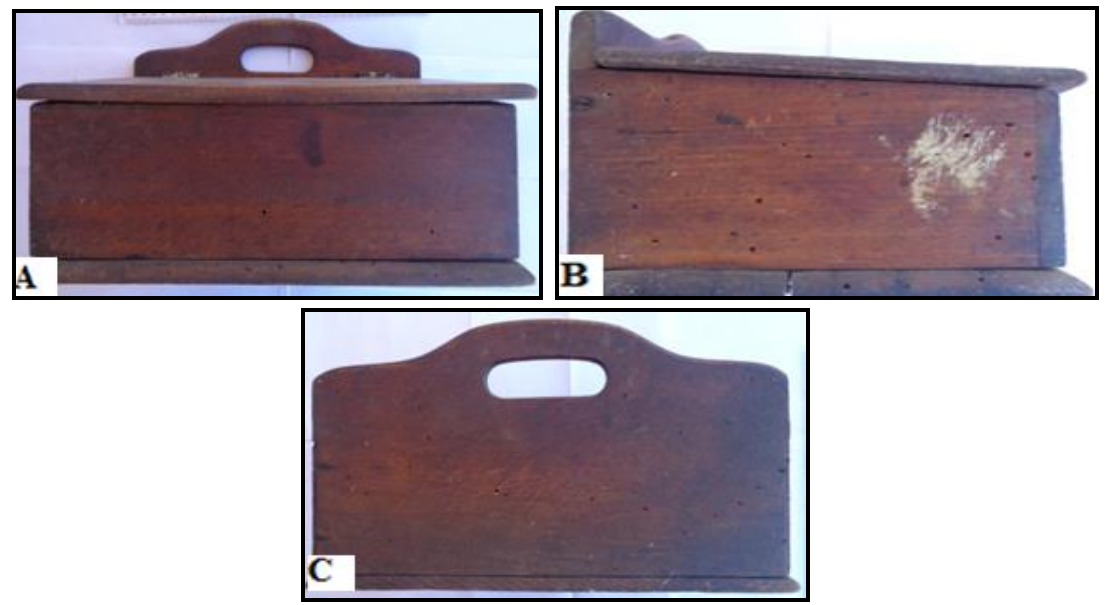

Fig.10. Old wooden Box
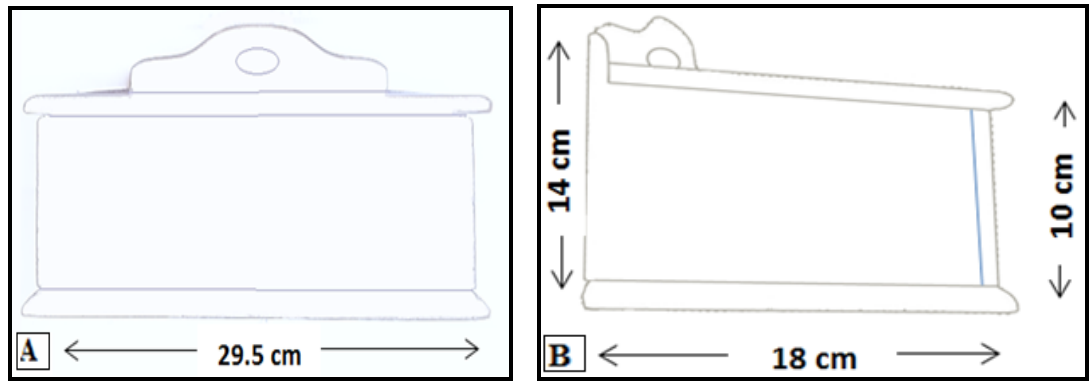

Fig.11. The dimension of old wooden Box

\section{2- 1- 3- 1- Wood used:}

\section{2- 1- 3- 1-1- Beech wood}

Fagus sylvatica $L$.

Family: Fagaceae.

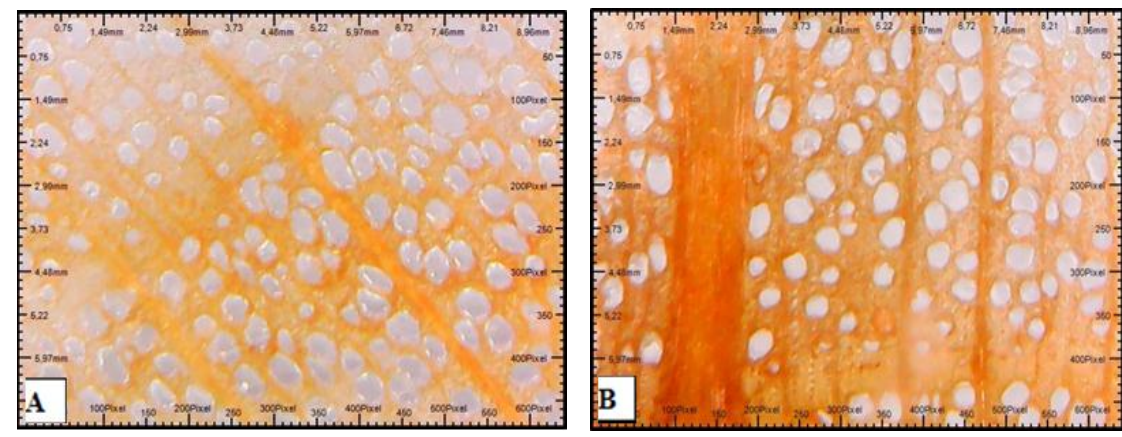

Fig.12. Cross-section of Fagus sylvatica $L$. 
- Damage Caused by the Furniture Beetle (Anobium punctatum) on Cultural and Historic Hardwood types "Case Study"

\section{2- 1- 4- Old wooden Mallet:}

These types of mallets are used for many purposes such as, carpentry works like assembling the pieces of wood and for the fine carving with chisels. Only the head is ancient with dimension $17 \times 9 \mathrm{~cm}$.
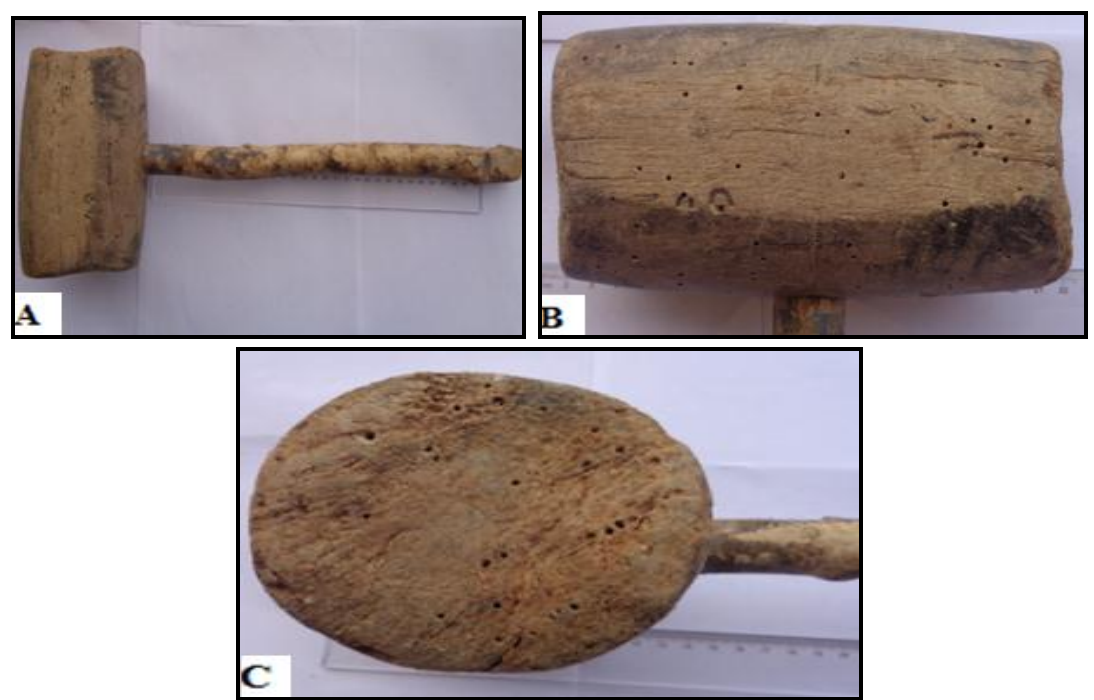

Fig.13. Old wooden Mallet.

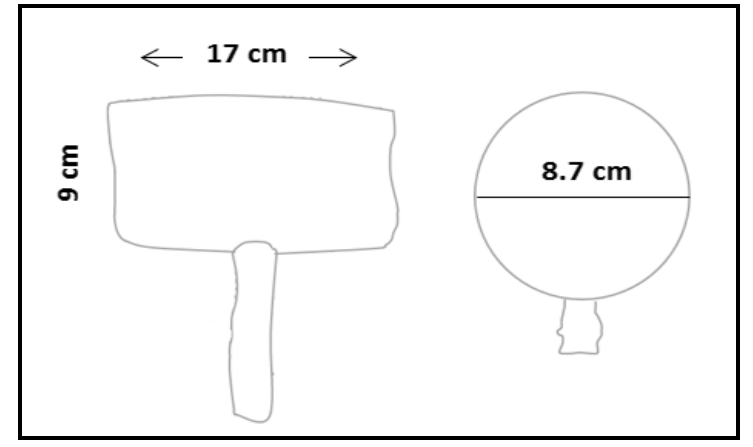

Fig.14. The dimension of old wooden Mallet

\section{2- 1- 4- 1- Wood used:}

\section{2- 1- 4- 1-1- Walnut wood}

Juglans regia $L$ 
Family: Juglandaceae

Walnut wood, Juglans regia L. belongs to genus Juglans (Juglandaceae), which includes almost 7- 45 species depending on the taxonomic study (Wan, et al.2014). Its agriculture spread throughout southern Europe, North Africa and East Asia (Abu Taha., AlWadaan., 2011), Walnut is a diffuse-to-semi-ring porous wood, with large pore of $4-5 \mathrm{~cm}$ per $\mathrm{mm}^{2}$ (Akkemik. 2013). This wood is used in furniture and woodworking. (Benoit.2002)
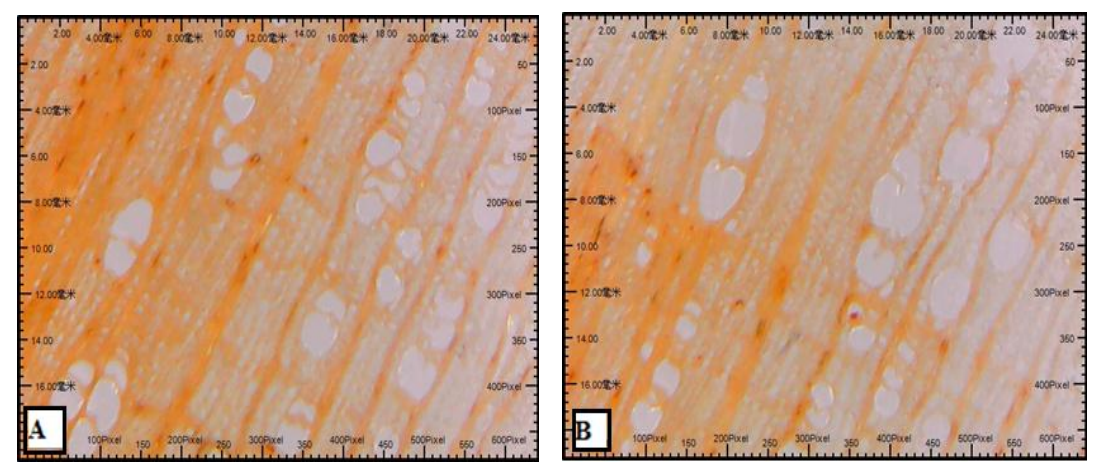

Fig.15. cross-section of Fagus sylvatica $L$.

\section{2- 1- 5- Old wooden plane:}

One of the hand tools of carpentry used in the planning of wood surface, with dimensions $21 \times 5.5 \times 11$ $\mathrm{cm}$. 
- Damage Caused by the Furniture Beetle (Anobium punctatum) on Cultural and Historic Hardwood types "Case Study"
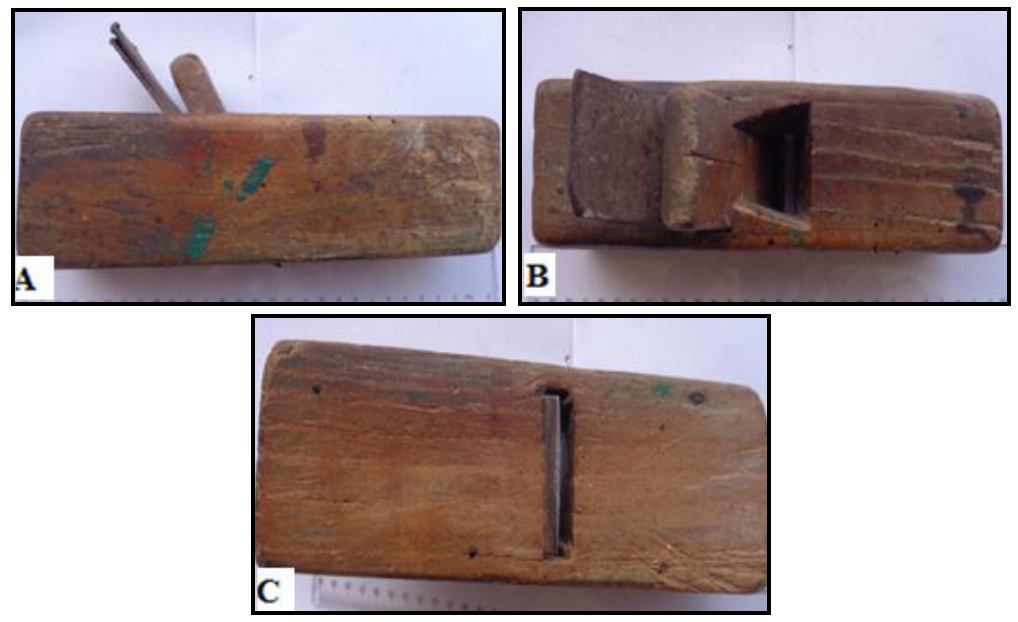

Fig.16. Old wooden plane.

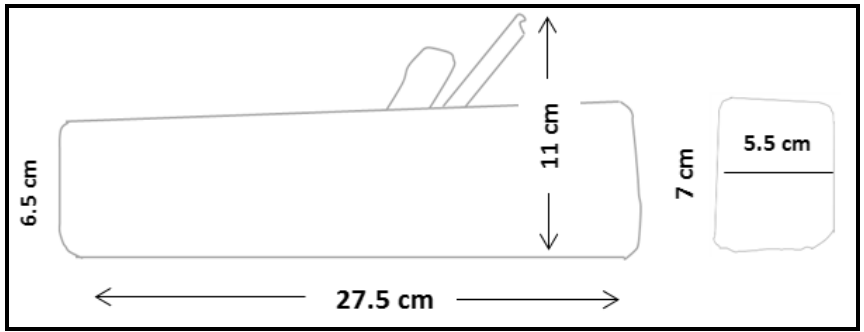

Fig.17. The dimension of old wooden plane.

\section{2- 1- 5- 1- Wood used:}

\section{2- 1- 5- 1-1- European Ash:}

Fraxinus excelsior $L$.

Family: Oleaceae.

The ash (Fraxinus excelsior) is a tree of the family Oleaceae, it is a ring porous wood (Rak., Merev. 2016), with high elasticity (flexibility), low in natural durability for both sapwood and heartwood and not resistant to insect attacks. (Giachi. et al. 2003). These trees are found in Europe, North America and Japan. (Walker. 2005) 

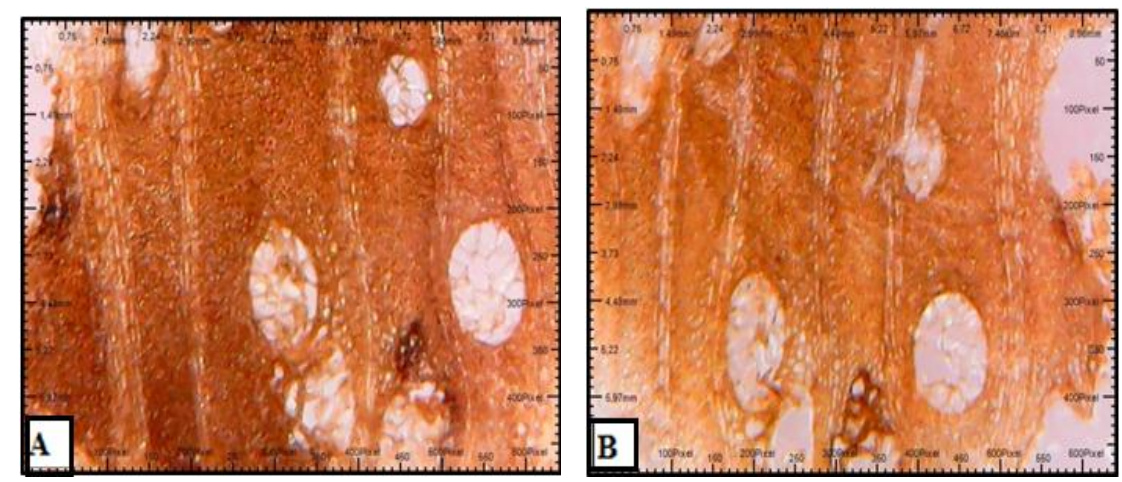

Fig.18. cross-section of Fraxinus excelsior $L$.

\section{3- Damage caused by Anobium punctatum on the selected artifacts:}

To study the effect of this insect on these wooden artifacts several examination methods were used: visual, magnifying lenses and a digital USB microscope. Through examination resulted in the following observations:

\section{3-1- Old coffee grinder}

The ancient coffee grinder was the most affected object by Anobium punctatum, where the damage spread out through all the pieces and in all the wood which was used although it was composed of various types. The exit holes had spread out in all parts, were circular and their diameter ranged between 1-3 $\mathrm{mm}$, separate or contiguous. The tunnels are irregular shaped and diffused in the whole mass of all the wood which is used and leaving only a thin layer on the surface of the damaged wood that can break down under little pressure.

During the examination of tunnels, exit flight holes and the cracks, separate ellipsoidal frass pellets and dust were found with some remains of the adult insect and complete adult insect and living larvae. 
- Damage Caused by the Furniture Beetle (Anobium punctatum) on Cultural and Historic Hardwood types "Case Study"

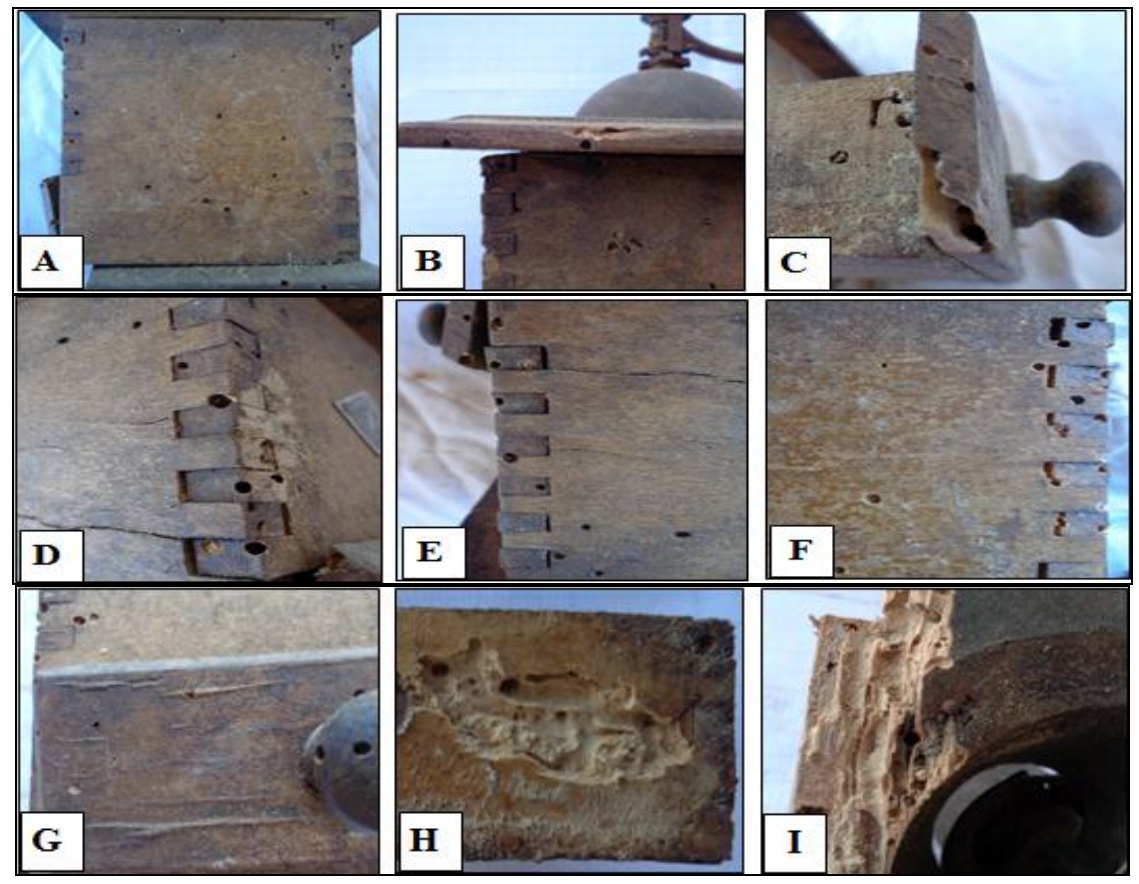

Fig.19. Damage characteristics of the old coffee grinder by Anobium punctatum.

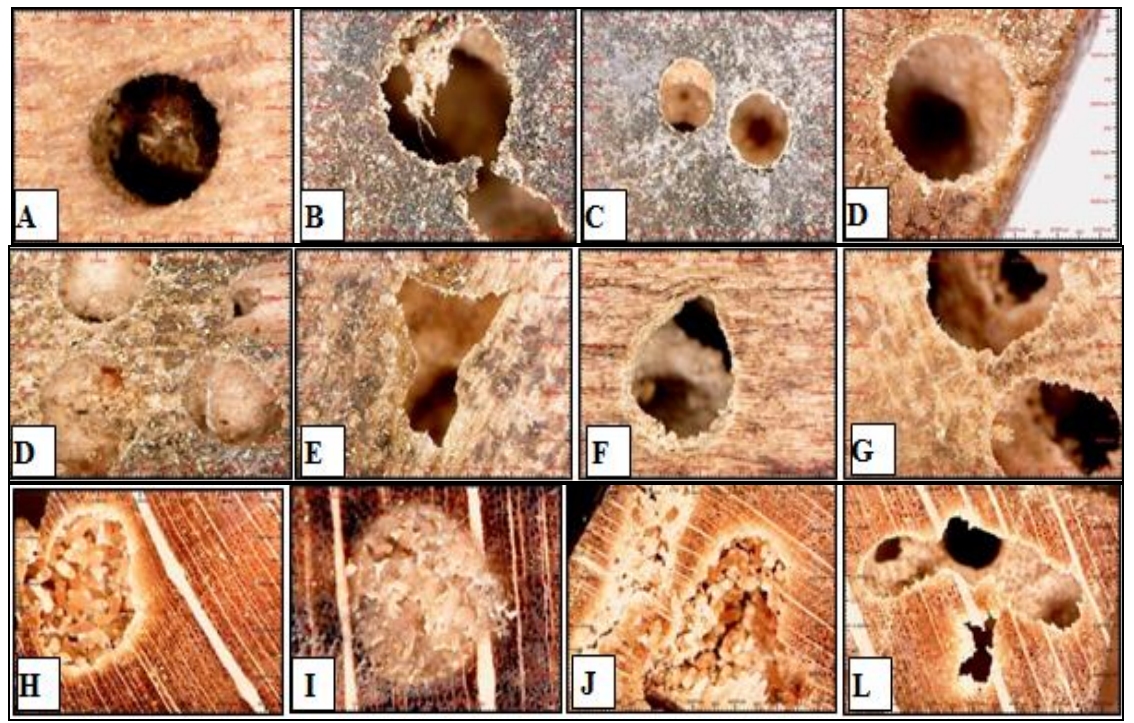

Fig.20. Damage characteristics of the old coffee grinder by Anobium punctatum (USB. D. M) 
Damage Caused by the Furniture Beetle (Anobium punctatum) on Cultural and Historic Hardwood types "Case Study"
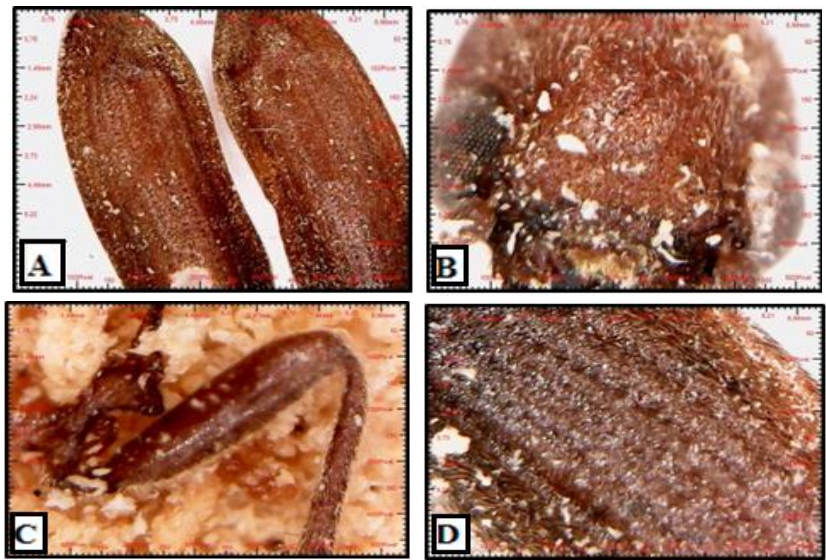

Fig.22. Remains of the insect Anobium punctatum found in the damaged wood.
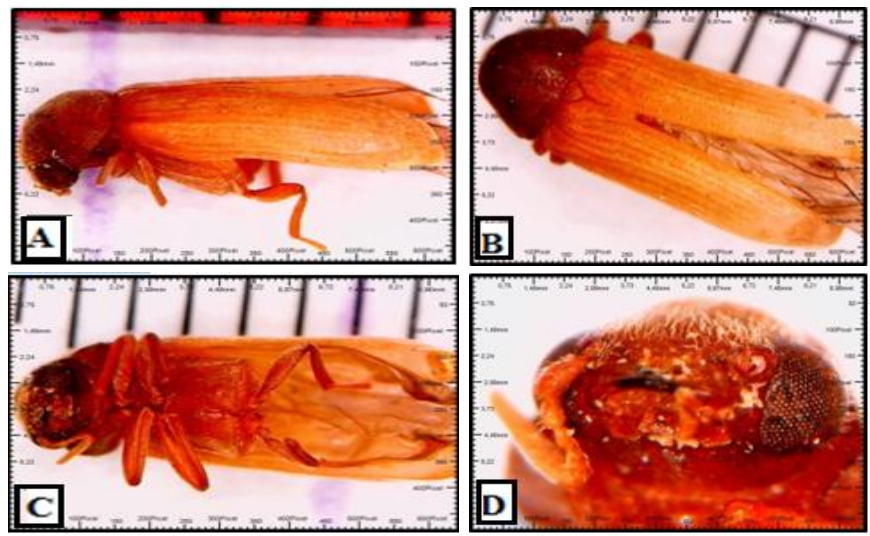

Fig.23. Complete adult Anobium punctatum found inside the damaged wood.

\section{3-2- Old Mason's moulded brick jointer:}

The damage spread in the entire wooden piece that was used in the study. The exit holes, which are circular and 1-3 $\mathrm{mm}$ in diameter, may be separate or contiguous, (in this case they may merge with each other leading to the formation of larger exit holes, taking different forms).

During the examination the exit flight holes and the cracks, separate ellipsoidal frass pellets and dust, 
- Damage Caused by the Furniture Beetle (Anobium punctatum) on Cultural and Historic Hardwood types "Case Study"

were found with some remains of the adult insect and eggs.

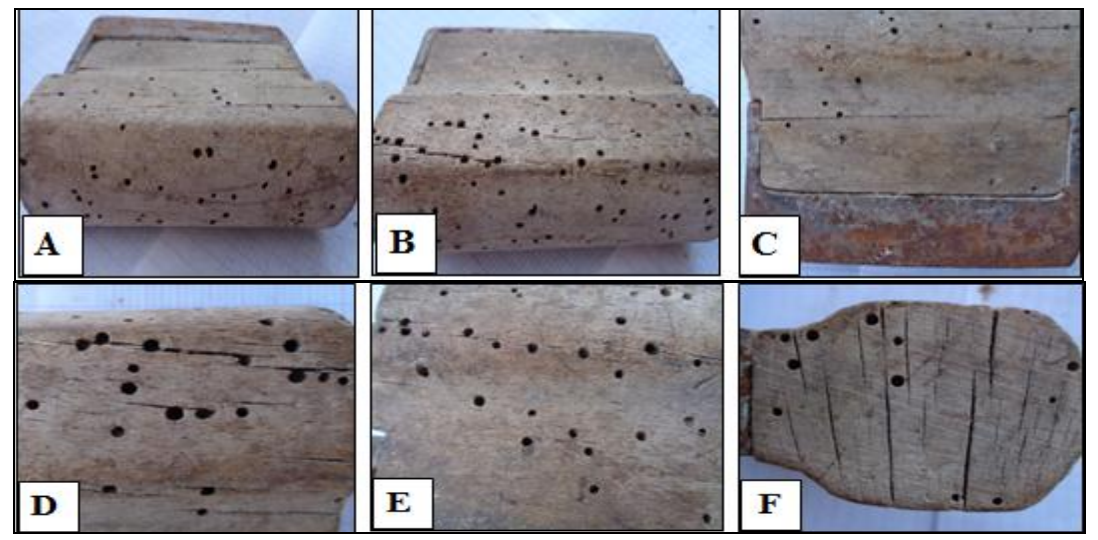

Fig.24. Damage characteristics of the old Mason's moulded brick jointer by Anobium punctatum.

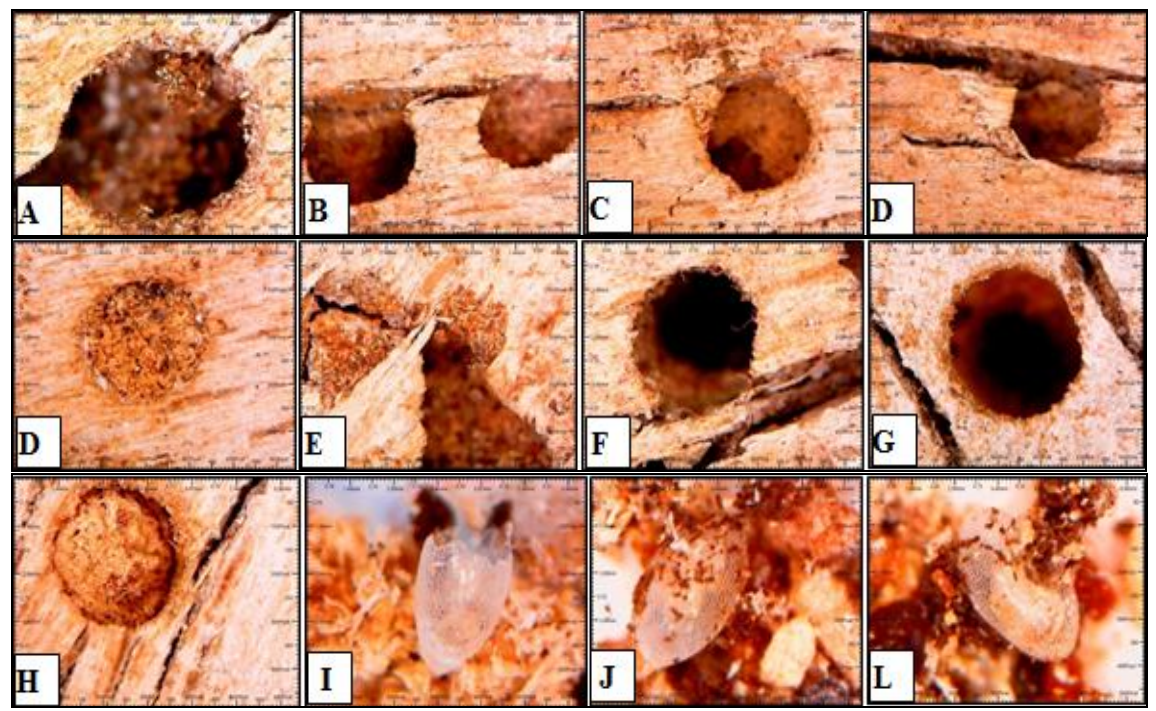

Fig.25. Damage characteristics of the old Mason's moulded brick jointer by Anobium punctatum, I, J and L. show some parts of the eggs of this insect. 
Damage Caused by the Furniture Beetle (Anobium punctatum) on Cultural and Historic Hardwood types "Case Study"

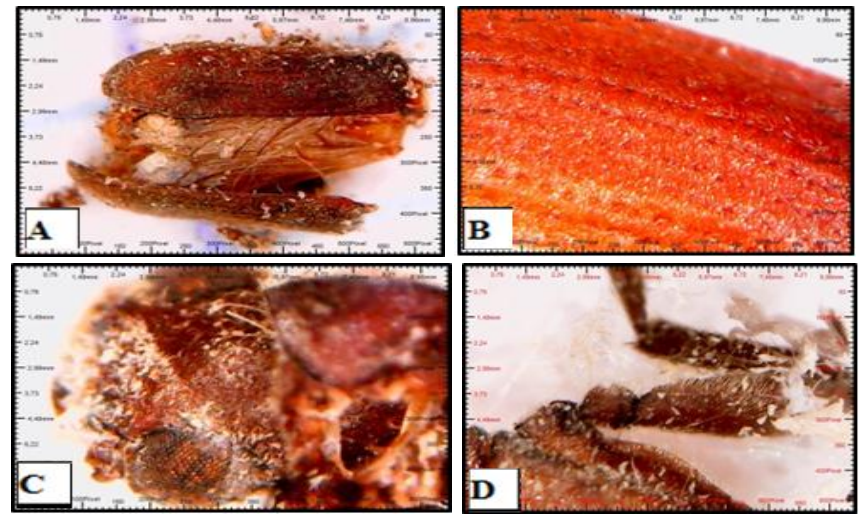

Fig.26. Remains of the insect Anobium punctatum found in the infested wood.

\section{3- 3- Old wooden Box:}

The damage is spreading in all the pieces of wood that are used. The exit holes have spread which are circular and 1-3 $\mathrm{mm}$ in diameter, these exit holes spread separately. During the examination of the exit flight holes and the cracks, separate ellipsoidal frass pellets and dust, were found with some remains of the adult insect and eggs, in addition to complete adult insect.
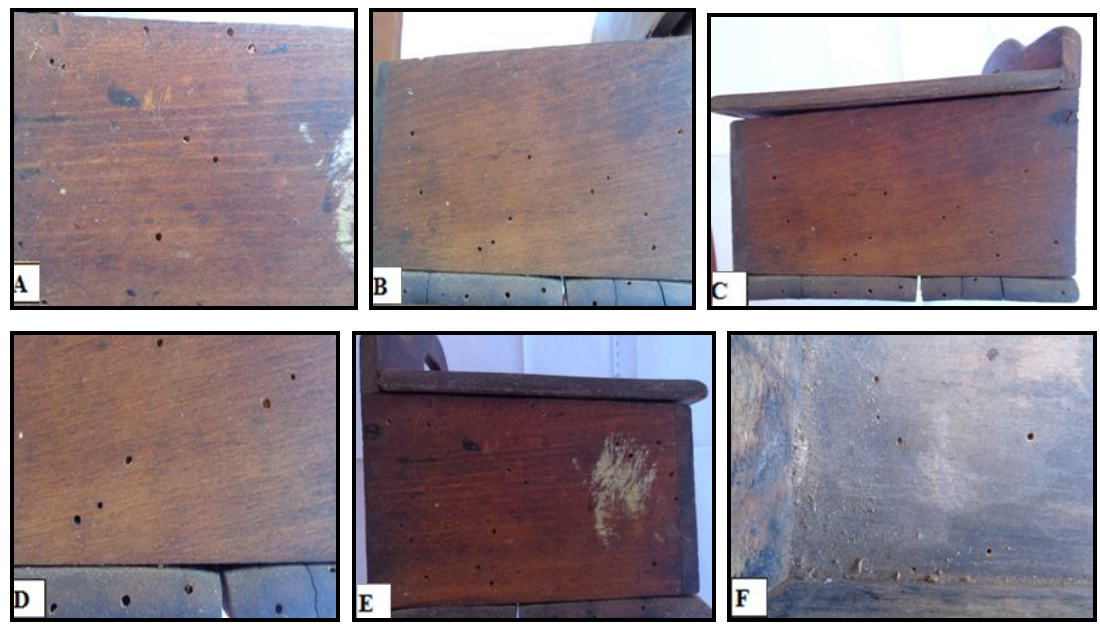

Fig.28. Damage characteristics of the old wooden box by Anobium punctatum 
- Damage Caused by the Furniture Beetle (Anobium punctatum) on Cultural and Historic Hardwood types "Case Study"
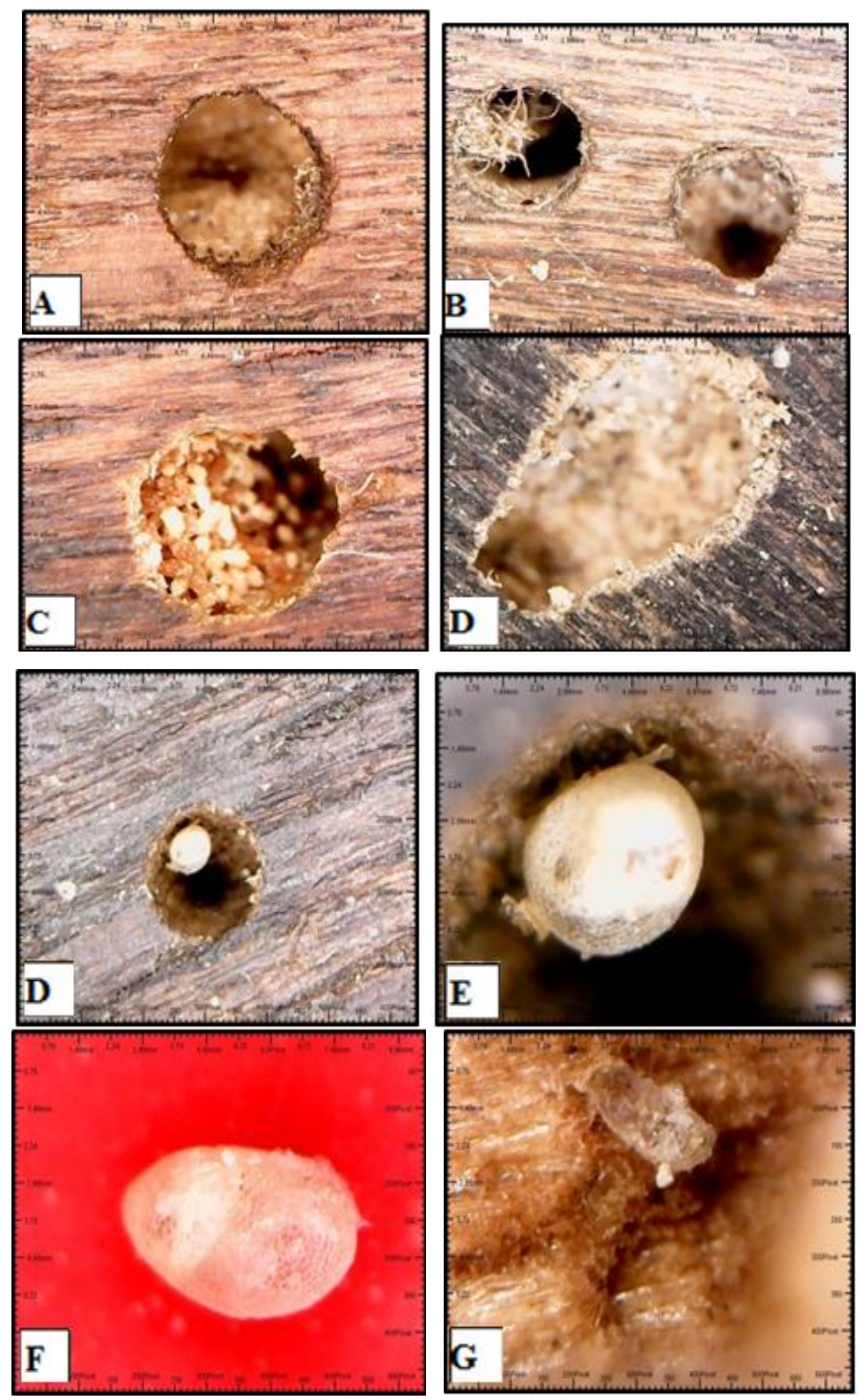

Fig.29. Damage characteristics of the old wooden box by Anobium punctatum and, D-G. show the eggs of this insect. 
Damage Caused by the Furniture Beetle (Anobium punctatum) on Cultural and Historic Hardwood types "Case Study"
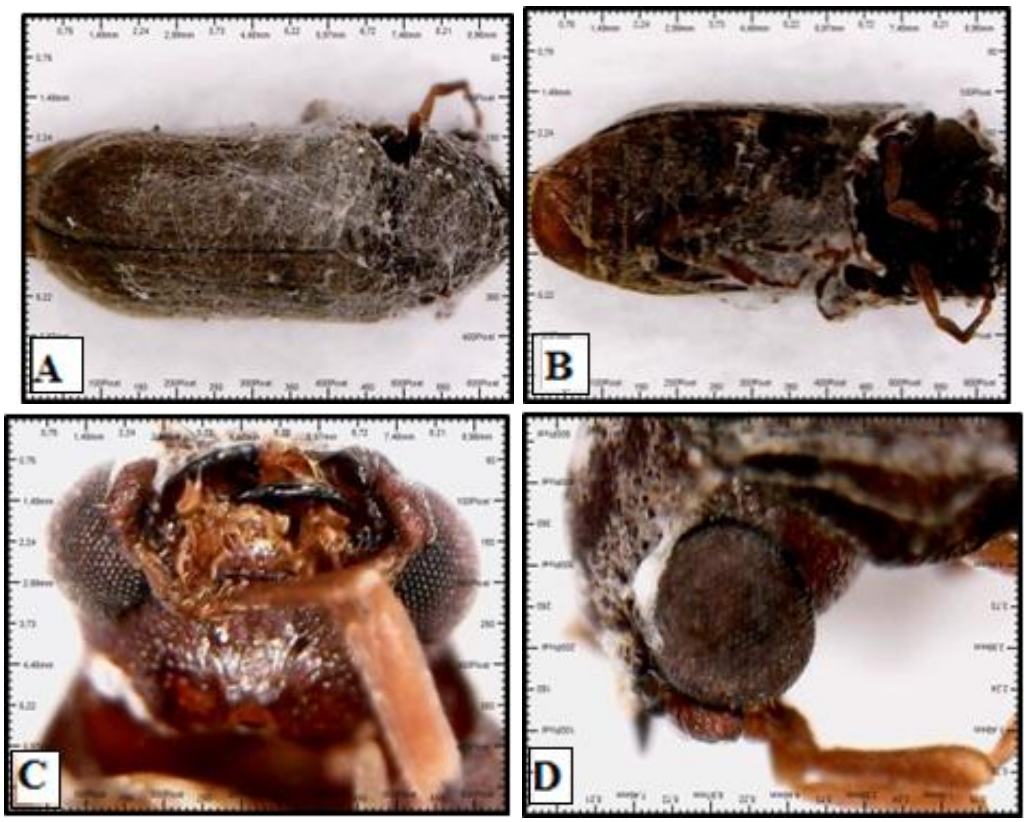

Fig.31. Complete insect Anobium punctatum found in the damaged wood.

\section{3- 4- Old wooden Mallet:}

The damage spread in the entire wooden piece. The exit holes, which are circular and 1-3 $\mathrm{mm}$ in diameter, may be separate or contiguous, (in this case they may merge with each other leading to the formation of larger exit holes, taking different forms). During the examination the exit flight holes and the cracks, separate ellipsoidal frass pellets and dust were found with some remains of the adult insect.
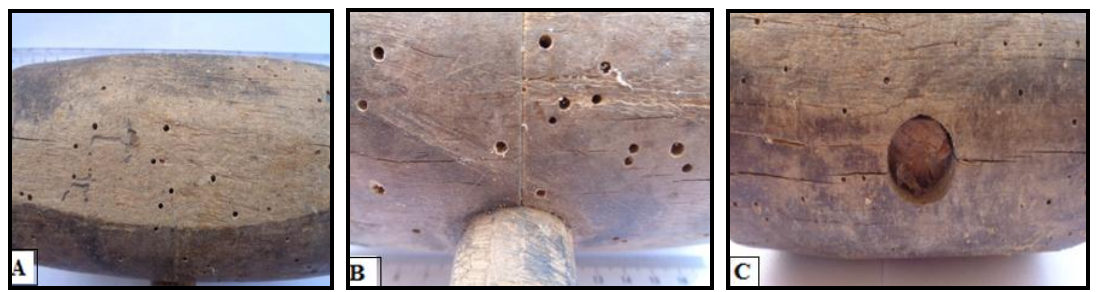
- Damage Caused by the Furniture Beetle (Anobium punctatum) on Cultural and Historic Hardwood types "Case Study"
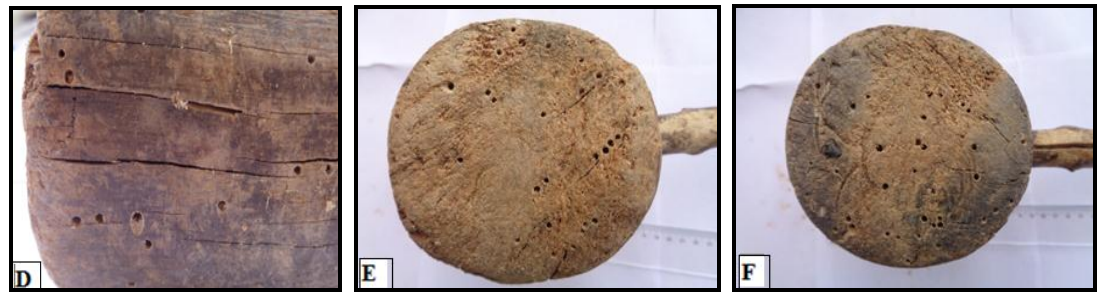

Fig.32. Damage characteristics of the old wooden mallet by Anobium punctatum.
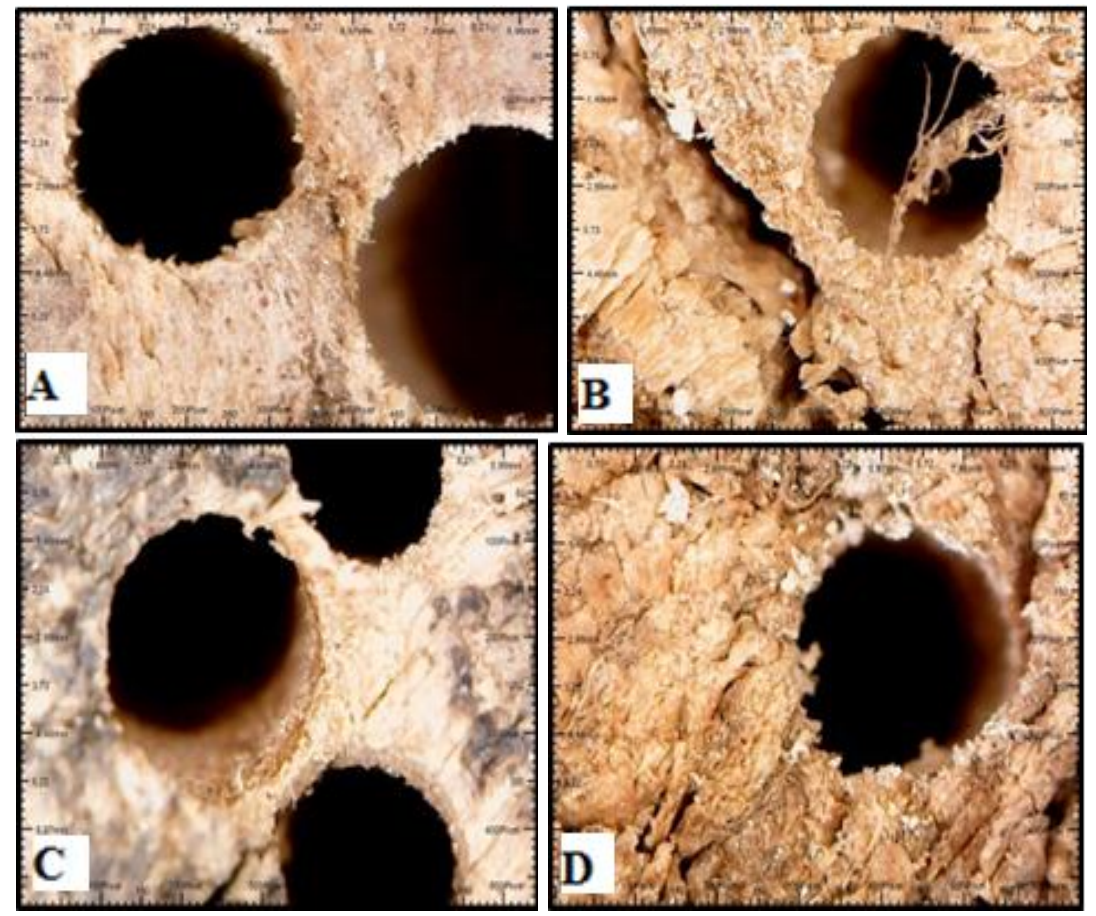

Fig.33. Damage characteristics of the old wooden mallet by Anobium punctatum. 
Damage Caused by the Furniture Beetle (Anobium punctatum) on Cultural and Historic Hardwood types "Case Study"
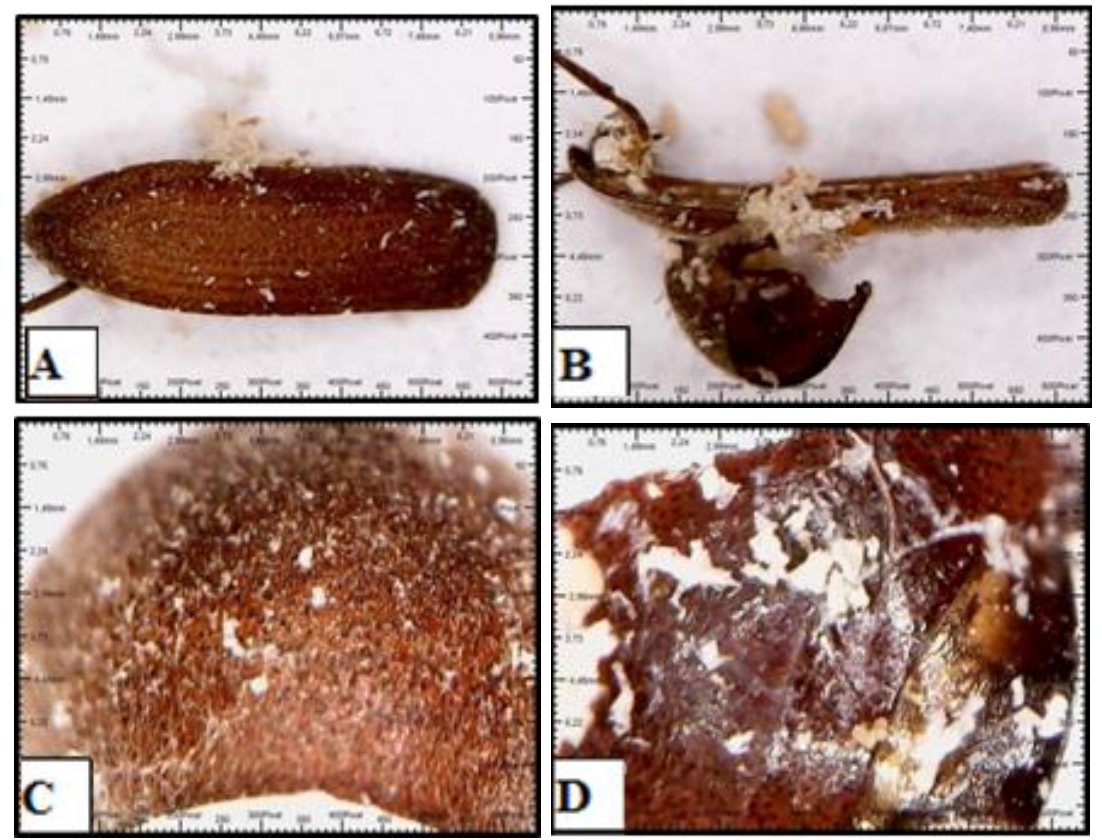

Fig.35. Remains of the insect Anobium punctatum that were found in the damaged wood.

\section{3-5- Old wooden plane:}

The damage spread in the entire wooden piece, but less than previous objects. The exit holes, which are circular and 1-3 $\mathrm{mm}$ in diameter, spread separately. During the examination the exiting flight holes and the cracks, separate ellipsoidal frass pellets and dust were found with some remains of the adult insect.
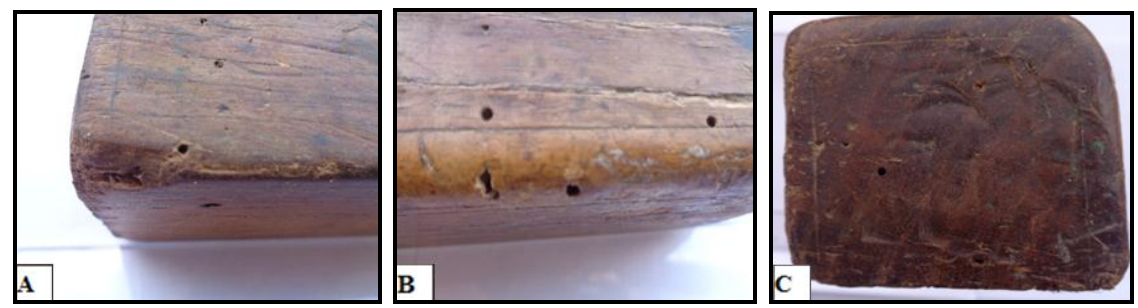

Fig.36. Damage characteristics of the old wooden plane by Anobium punctatum 
- Damage Caused by the Furniture Beetle (Anobium punctatum) on Cultural and Historic Hardwood types "Case Study"
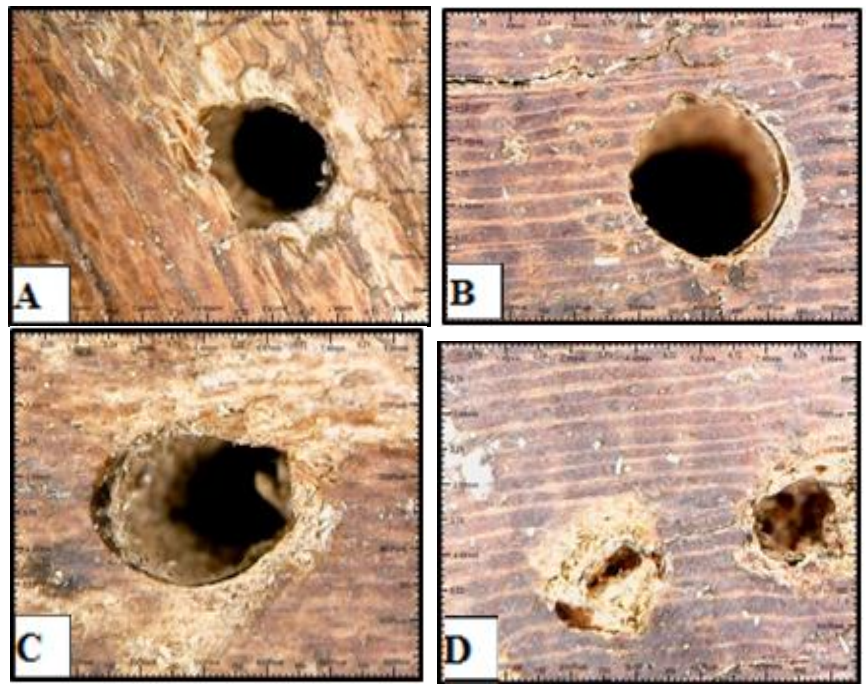

Fig.37. Damage characteristics of the old wooden plane by Anobium punctatum.
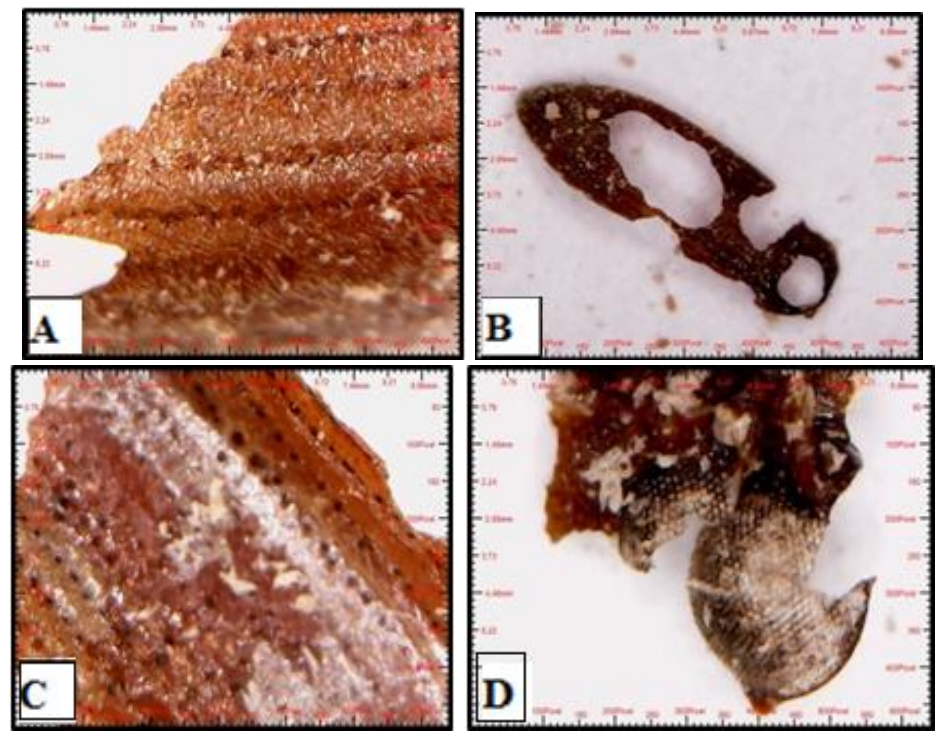

Fig.38. Remains of larva and the insect Anobium punctatum found in the damaged wood.

\section{Results Discussion:}

\section{Identification of Types of wood:}

During this study, some types of wood have been identified as follow: 
Fagus sylvatica $L$ : this wood was used in making some parts of the wooden coffee grinder, in the wooden Mason's moulded brick jointer and in the wooden Box.

Populus nigra L: this wood was used in making some parts of the wooden coffee grinder.

Platanus occidentalis $L$ : this wood was used in making some parts of the wooden coffee grinder.

Quercus robur $L$ : this wood was used in making some parts of the wooden coffee grinder.

Juglans regia $L$ : this wood was used in the wooden Mallet.

Fraxinus excelsior $L$ : this wood was used in the wooden plane.

\section{Diagnosis of the damage of Anobium punctatum:}

This study shows the destructive effect of Furniture beetle (Anobium punctatum) on all Types of wood that were used in the selected wooden artifacts, this can be seen by the spread of tunnels and exit flight holes within all types of Hardwood used without distinction of wood type.

Through the examination by USB digital microscope of the various woods, the effect of the furniture beetle (Anobium punctatum) is clear on all parts of wood. This is Confirmed by previous studies, which indicate the effect of Furniture beetle (Anobium punctatum) on both hardwood and softwood in particular Sapwood area (French, 1968) (kaygin, et al, 2008), where the tunnels and the exit flight holes spread uniformly in all parts of the damaged wood.

The study also shows the effect of Furniture beetle (Anobium punctatum) on all the anatomical elements of the hardwood, as we are observing a lot of tunnels and the exit flight holes spread within the wood texture without discrimination of fibers, vessels and wood rays. In addition to the spread of tunnels and exit flight holes 
- Damage Caused by the Furniture Beetle (Anobium punctatum) on Cultural and Historic Hardwood types "Case Study"

in both directions the longitudinal and the transverse, moreover, it was observed in some parts of oak wood that the tunnels have been formed in the earlywood area that are less density than latewood area (Gilfillan, et al, 1999).

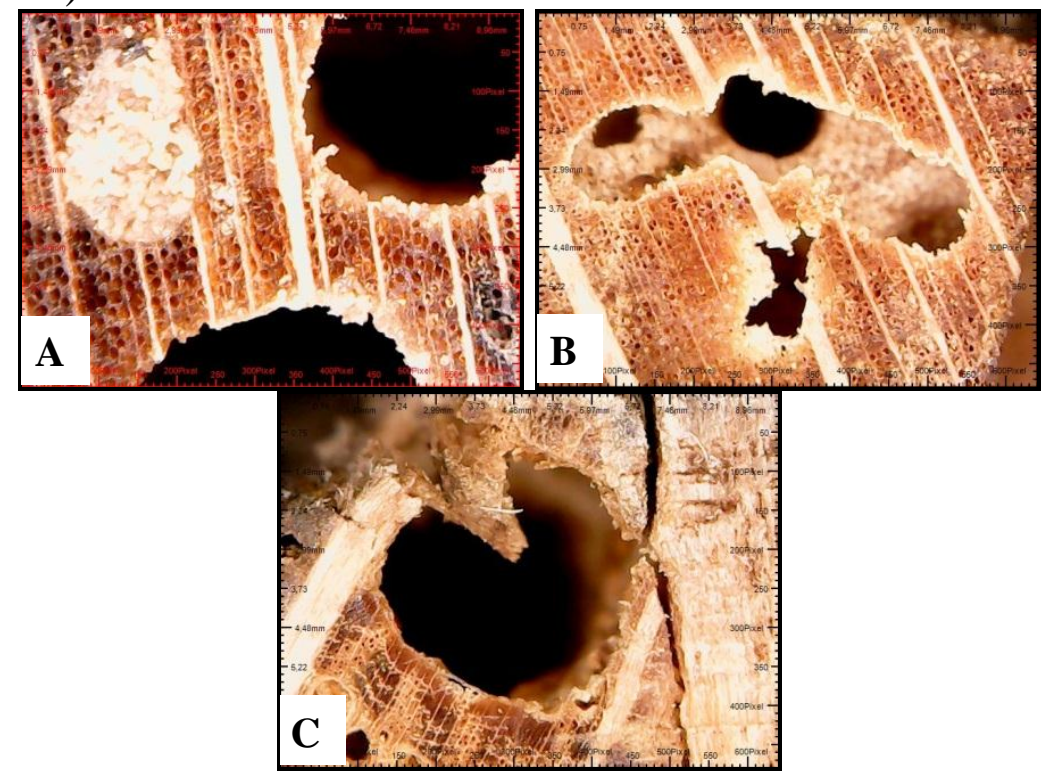

Fig.39. A\&B, The tunnels and the exit flight holes of Anobium punctatum spread within all the wood texture, $\mathrm{C}$, the formed tunnels in the earlywood area of oak wood.
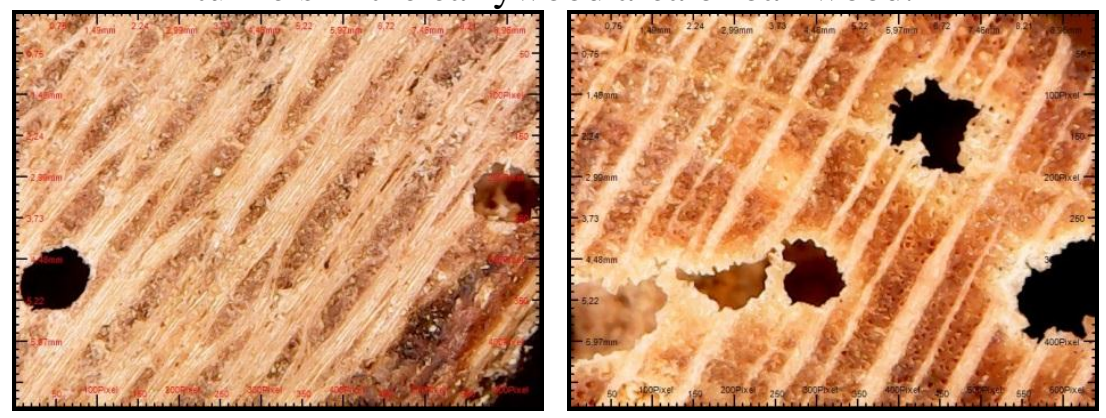

Fig.40. the spread of tunnels and exit flight holes in both directions the longitudinal and the transverse of damaged wood.

It is revealed, through this study, that, of all wooden artifacts, the wooden plane was least affected by the Anobium punctatum in the spread of tunnels and the exit flight holes. This is due to its preservation in a suitable place and under a constant observation. Since 
the surrounding environmental conditions of the wooden artifacts are the main factor in the preservation of human heritage.

The destructive effects of the furniture beetle (Anobium punctatum) on wooden artifacts appear when these artifacts are preserved or stored in unheated facilities or in basements that had high levels of humidity (French, 1968),(Child, Pinniger, 2014).

\section{4- Conclusions}

In the research six types of wood, that were used in the implementation of old wooden artifacts in France around 120 or 150 years ago, were identified: Fagus sylvatica L, Quercus robur L, Populus nigra L, Platanus occidentalis L, Juglans regia L, Fraxinus excelsior L. These six types of wood were used in the implementation of five different artifacts, indicating the previously multiple uses of these types of wood in France. But even so, we find that the manufacturer used a multiplicity of types of wood in the old coffee grinder, this may be an indicative of using smaller pieces of wood that were available in the carpentry workshop, where the manufacturer used four types of wood (Fagus sylvatica L, Quercus robur L, Populus nigra L, Platanus occidentalis L).

This study explains the impact of Anobium punctatum beetles on wooden artifacts (especially hardwoods), where small round exit holes are spread in approximately 1-3 $\mathrm{mm}$ in diameter on the surface of the damaged wood. In addition to that, we can observe the penetration of the irregular galleries and tunnels that the larvae excavated on damaged wood. These tunnels are parallel to the grain of the damaged wood. These tunnels are also full of the bore dust of the expendable wood and of the frass. These tunnels are spread under a very thin 
surface layer of the damaged wood. Also, the spread of these tunnels lead to the lowering of the strength and the mechanical properties of wood (Gilfillan, et al, 1999),(kaygin, et al, 2008).

\section{5- References:}

1. Abu Taha. N., Al-wadaan. M. A, (2011), Utility and importance of walnut, Juglans regia Linn: A review, African Journal of Microbiology Research, Vol. 5(32), pp. 5796-5805.

2. Akkemik. Ü, (2013), Woods of the old galleys of Yenikapi, İstanbul, Mediterranean Archaeology and Archaeometry, Vol. 13, N.2, pp. 31-41.

3. Benoit. Y, (2002), Le guide des essences de bois, EYROLLES, Paris, p. 31, 54.

4. Bianco. J. F, (1999), Anciens moulin à café, SELD, paris, pp. 8-9.

5. Bierling. P, (2007), Le pack menuiserie, SAEP, p. 10.

6. Busvine. J. R, (1980), Insects and Hygiene, The biology and control of insect pests of medical and domestic importance, $3^{\text {rd }}$ ed, Chapman and Hall, London, New York.

7. Child, R, Pinniger, D, (2014) Current status and treatments for Anobium Punctatum, OOK-Press Kft., H-8200 Veszprém, Papái ut 37/a, Hungary, pp.329-333.

8. Clausen. C. A, (1990) Biodeterioration of wood, In, Ross. R. J., Wood handbook wood as an engineering material, Forest Products Laboratory, United States Department of Agriculture Forest Service, Madison, Wisconsin, Centennial Edition, 2010, p. 15. 
9. Cronyn. J. M, (1990) The elements of archaeological conservation, Routledge, New York, p. 248.

10.Eaton. R. A., Hale. M. D. C, (1993), Wood decay, pests and protection, Chapman \& Hall, 1st Ed, London, p. 234

11.Feilden. B. M, (2003), Conservation of Historic Buildings, 3rd Ed, Elsevier, p. 146.

12.French, R, (1968), the distribution of the furniture beetle, anobium punctatum (de geer) (coleoptera: anobiidae), in New South Wales, J. Aust. ent. Soc. 7, pp. I15-122.

13.Giachi. G. et al, (2003), The wood of "C" and "F" Roman ships found in the ancient harbour of Pisa (Tuscany, Italy): the utilisation of different timbers and the probable geographical area which supplied them, Journal of Cultural Heritage 4, pp. 269-283.

14.Gilfillan. J. R, et al, (1999), the residual strength of timber degraded woodworm infestation, Proceedings of Durability of Building Materials and Components 8, vol. 1, NRC Research Press, Ottawa, pp. 714-722.

15.Jones. S, et al, (2007), Wood- Destroying Insect Diagnostic Inspection, The Ohio Department of Agriculture - Pesticide Regulation - Certification and Training Section, p. 21.

16.Jourez. B, (2010), Anatomie et identification des bois, Université de Liège, p. 54.

17.Kaygin. A. T., et al, (2008), An Important Wood Destroying Beetle: Anobium punctatum (De Geer (Coleoptera: Anobiidae) and Distribution of Western Blacksea Region, IRG 39th Annual Meeting, 25-29 May 2008, Istanbul, Turkey. www.irg-wp.com. 
18.Kisternaya. M., Kozlov. V, (2009) Wood science approach for the preservation of historic timber structures,

https://www.researchgate.net/publication/2659911 02, p.3.

19.Kretschmann. D. E, (2010) Mechanical Properties of wood In, Ross. R. J., Wood handbook wood as an engineering material, Forest Products Laboratory, United States Department of Agriculture Forest Service, Madison, Wisconsin, Centennial Edition, p.44.

20.Morrell. J, (2008) Wood Preservation, Commercial pesticide Applicator Training, university of Missouri, Columbia, p.7.

21.Mosneagu. M, (2012), The preservation of cultural heritage damaged by anobiids (Insecta, Coleoptera, Anobiidae) ,Academy of Romanian Scientists Annals - Series on Biological Sciences, Vol. 1, No. 2. pp 37-38

22.Munro. J. W., Hon. M. A, (1924), Beetles injurious to timber, Forestry commission bulletin. No.9, London.p23

23.Noldt. U., Noldt. G, (2013), Manual on Wooddestroying Insects and their Monitoring, University of Hamburg, Department Biology, Centre of Wood Science Leuschnerstrasse 91d; 21031 Hamburg/Germany P.19.

24.Rak. F. E., Merev. N, (2016), Ecological wood anatomy of Fraxinus L. in Turkey (Oleaceae): intraspecific and interspecific variation, Turkish Journal of Botany. 357

25.Richebé. M, (2006), Entretenir et restaurer le bois, Gründ, Paris, p. 13. 
26.Robinson. W. H, (2005), Urban Insects and Arachnids A Handbook of Urban Entomology, Cambridge University Press, New York, pp. 66-67

27.Teles. C. D. M., Valle. Â. D, (2001) Wood structures: Acting before deterioration, Historical construction, P.B. Lourenco, P.Roca (Eds) Guimarães, p.860.

28.Tian. P, (2002) Biodegradation of cultural Heritage, Decay Mechanisms and control Methods, without date, www.Arcehip.cz/wog/wog_tiano.PDF, p. 10.

29.Tsoumis. G, (1991), Science and Technology of wood, Structure, properties, Utilization, VNR, New York, p.223.

30.Unger. A, et. al, (2001) Conservation of wood artifacts, Springer-Verlag Berlin Heidelberg, Germany, p. 62.

31.Urban. J, (2005), Occurrence, development and harmfulness of the bark anobiid Ernobius mollis(L.) (Coleoptera: Anobiidae), Journal of Forest Science, 51, (8), PP. 327-347.

32. Vilà. J. G. et. Al, (2013), Le grand livre du bois, Place Des Victoire. Chine, p.46.

33.Walker. D. (2005), L'Encyclopédie du bois, Hachette Pratique.

34.Wan. M. S., et al, (2014), Effect of altitude on the Morpho-phenological parameters of Juglans regia L. from different sites of Kashmir Himalay, International Journal of Advanced Research (IJAR) Volume 2, Issue 7, pp.97-110.

35. Zabel. R. A., Morrell. J. J, (1992) Wood microbiology decay and its prevention, Academic press Inc, p.29. 